\title{
PENGARUH MODEL PEMBELAJARAN GUIDED DISCOVERY LEARNING TERHADAP KEMAMPUAN PEMAHAMAN DAN HASIL BELAJAR SISWA MATERI OPERASI ALJABAR KELAS VII SMP
}

\author{
Ferennita Harianti \\ Institut Agama Islam Negeri (IAIN) Tulungagung \\ ferennita77@gmail.com
}

\begin{abstract}
ABSTRAK
Rendahnya kemampuan pemahaman siswa terhadap persoalan matematika karena pembelajaran matematika masih berpusat kepada guru. Penggunaan model pembelajaran secara konvensional yang mengakibatkan rendahnya kemampuan pemahaman serta hasil belajar. Maka dari itu guru sebaiknya dapat menggunakan model pembelajaran salah satunya ialah Guided Discovery Learning. Tujuan penelitian ini adalah untuk mengetahui pengaruh model pembelajaran Guided Discovery Learning terhadap kemampuan pemahaman dan hasil belajar siswa materi operasi aljabar kelas VII. Metode penelitian ini adalah kuantitatif. Dengan desain penelitian onegroup pretest-posttest design. Populasi penelitian seluruh siswa kelas VII SMP Negeri 2 Sumbergempol. Sampel penelitian kelas VII-G dengan jumlah siswa sebanyak 32 siswa. Teknik pengumpulan data berupa soal tes pilihan ganda 10 dan uraian 5 soal pretest dan posttest serta dokumentasi. Data dioleh dengan menggunakan analisis uji-t. Hasil penelitian menunjukkan bahwa kemampuan pemahaman siswa terhadap materi operasi aljabar setelah mendapatkan model pembelajaran guided discovery learning menggunakan uji-t diperoleh $0,000<0,05$ maka artinya Ho ditolak, dan secara otomatis $\mathrm{Ha}_{1}$ yang diterima artinya ada pengaruh penggunaan model pembelajaran guided discovey learning terhadap kemampuan pemahaman siswa materi operasi aljabar kelas VII. Sedangkan hasil belajar siswa terhadap materi operasi aljabar setelah mendapatkan model pembelajaran Guided Discovery Learning menggunakan uji-t diperoleh 0,000 $<0,05$ maka artinya Ho ditolak, dan secara otomatis $\mathrm{Ha}_{2}$ yang diterima artinya ada pengaruh penggunaan model pembelajaran guided discovey learning terhadap hasil belajar siswa materi operasi aljabar kelas VII.
\end{abstract}

Kata kunci: hasil belajar, kemampuan pemahaman, pembelajaran guided discovery learning.

\begin{abstract}
The low ability of students' understanding of the mathematical problems because the learning of mathematics is still centered on the teacher. The use of conventional learning model resulting in low comprehension and learning outcomes. Therefore the teacher should be able to use the learning model one of them is Guided Discovery Learning. The purpose of this study is to determine the effect of Guided Discovery Learning model of learning ability and learning outcomes of students of class VII algebraic operations. This research method is quantitative. With one-group research design pretest-posttest design. Research population of all students of class VII SMP Negeri 2 Sumbergempol. The sample of research class VII-G with the number of students as many as 32 students. The data collection technique is a matter of multiple choice test 10 and description of 5 pretest and posttest questions and documentation. Data were obtained using t-test analysis. The results showed that students' understanding of algebraic material after obtaining the learning model of guided discovery learning using t-test obtained $0.000<0,05$ then means Ho rejected, and automatically $\mathrm{Ha}_{1}$ received means there is influence of the use of guided discovery learning model of learning ability students' understanding of the subject matter of class VII algebra. While the result of student learning to the material of algebra operation after getting Guided Discovery Learning model using t-test obtained 0,000 $<0,05$ then mean Ho rejected, and automatically $\mathrm{Ha}_{2}$ accepted mean there is influence of using guided discovery learning model to student learning result operation of class VII algebra.
\end{abstract}

Keywords: learning outcomes, understanding ability, guided discovery learning. 


\section{Ferennita Harianti}

\section{PENDAHULUAN}

Menurut Undang-Undang Nomor 20 tahun 2003 tentang Sistem Pendidikan Nasional, pasal 1 angka 1 menyatakan bahwa pendidikan adalah usaha sadar dan terencana untuk mewujudkan suasana belajar dan proses pembelajaran agar peserta didik secara aktif mengembangkan potensi dirinya untuk memiliki kekuatan spiritual keagamaan, pengendalian diri, kepribadian, kecerdasan, akhlak mulia, serta keterampilan yang diperlukan dirinya, masyarakat, bangsa dan negara. Selanjutnya menurut Risnawati (2008) dalam Firdaus mengatakan pendidikan tidak dapat lepas dari masalah pembelajaran karena merupakan inti dari proses pendidikan, peningkatan kualitas pendidikan menunjukkan hasil belajar siswa tersebut. Maka dari itu pendidikan yang berkualitas dapat meningkatkan potensi dan mengembangkan diri. Namun pada umumnya pembelajaran matematika berpusat kepada guru. Akibat dari pembelajaran yang berpusat pada guru ialah ketika guru sedang menjelaskana siswa akan ramai sendiri. Metode ceramah pun menjadi pilihan guru dalam membawakan materi matematika. Sehingga guru hanya mentransfer ilmu kepada siswa tanpa memperhatikan siswa memahami atau tidak materi yang disampaikan. Proses pembelajaran yang terjadi hanya satu arah, dimana siswa hanya mencatat dan menyelesaikan soal yang telah dikerjakan oleh guru. Hal ini mengakibatkan siswa cenderung pasif. Siswa hanya diam dan mendengarkan penjelasan dari guru serta tidak bertanya apabila mereka merasa tidak bisa. Maka dari itu siswa tidak dapat mengembangkan dan mengkontruksi pengetahuannya sendiri. Dengan kondisi kelas yang seperti itu hasil belajar siswa tidak bisa maksimal bahkan dibawah kriteria ketuntasan minimal. Salah satu mata pelajaran terpenting ialah matematika. Hal ini dilihat dari tidak dapat dipisahkannya pembelajaran matematika pada semua jenjang pendidikan mulai dari sekolah dasar, menengah, maupun universitas. Alasan yang mendukung penyataan tersebut adalah untuk membekali diri siswa dengan kemampuan analisis, berpikir kritis, dan kreatif (Riftakhul Ardi Bakhtiyar, 2017)

Belajar matematika menggunakan metode konvensional kurang efektif, kurang efektif ini berarti pemahaman siswa itu cepat lupa akibatnya pada pertemuan-pertemuan berikutnya siswa ditanya tidak bisa menjawab (Abdul 
Kholik, 2016). Siswa hanya diam dan mendengarkan tanpa mendapat kesempatan untuk mengkontruksi pengetahuannya sendiri. Sehingga tingkat pemahaman dan hasil belajar terhadap matematika rendah.

Kemampuan pemahaman sangat dibutuhkan oleh siswa karena siswa dituntut untuk dapat menyelesaikan persoalan matematika sendiri. Dalam proses pembelajaran siswa lebih banyak belajar sendiri sehingga siswa menjadi subjek yang belajar. Saat ini model-model pembelajaran sudah banyak berkembang dimana siswa dapat memahami materinya secara mandiri. Salah satu model pembelajaran yang memungkinkan untuk meningkatkan kemampuan pemahaman serta hasil belajar ialah Guided Discovery Learning. Siswa mendapatkan pemahaman yang lebih baik serta hasil belajar pun meningkat setelah menggunakan model pembelajaran Guided Discovery Learning. Selain itu dengan menggunakan model pembelajaran Guided Discovery Learning dapat melatih siswa untuk menemukan sendiri konsep agar tidak mudah lupa.

Menurut Satyawati (2011) dalam Khilya Ulfa pembelajaran Guided Discovery Learning (penemuan terbimbing) adalah suatu pembelajaran tempat guru berperan menyatakan persoalan, kemudian membimbing siswa untuk menemukan penyelesaian persoalan itu dengan perintah-perintah atau lembar kerja siswa dan siswa mengikuti petunjuk dan menemukan sendiri penyelesaiannya. Seperti dalam penelitian yang dilakukan oleh Khilya Ulfa dkk untuk mengetahui perbedaan antara kemampuan pemecahan masalah matematika siswa pada pembelajaran Guided Discovery Learning untuk video pembelajaran dan model konvensional, apakah kemampuan pemecahan masalah matematika siswa yang menggunakan model pembelajaran Guided Discovery Learning untuk video pembelajaran lebih baik dari siswa yang menggunakan model pembelajaran konvensional. Apakah kemampuan pemecahan masalah matematika siswa yang diberikan perlakuan mencapai tuntas secara klasikal maupun individual.

Tujuan penelitian ini untuk mengetahui adakah pengaruh model pembelajaran Guided Discovery Learning terhadap kemampuan pemahaman dan hasil belajar siswa materi operasi aljabar kelas VII. Apakah model pembelajaran 


\section{Ferennita Harianti}

guided discovery learning tersebut lebih baik dari pada pembelajaran konvensional.

\section{METODE PENELITIAN}

Dalam melakukan penelitian disiapkan hipotesis atau jawaban sementara terhadap penelitian yang dilakukan. Maka selanjutnya penelitian ditindak lanjuti untuk membuktikan apakah hipotesis itu benar adanya atau tidak. Berikut hipotesis dalam penelitian yang dilakukan.

\section{Hipotesis kemampuan pemahaman:}

$\mathrm{Ha}_{1}$ : ada pengaruh penggunaan model pembelajaran guided discovey learning terhadap kemampuan pemahaman siswa materi operasi aljabar kelas VII.

$\mathrm{Ho}_{1}$ : tidak ada pengaruh penggunaan model pembelajaran guided discovey learning terhadap kemampuan pemahaman siswa materi operasi aljabar kelas VII.

\section{Hipotesis hasil belajar:}

$\mathrm{Ha}_{2}$ : ada pengaruh penggunaan model pembelajaran guided discovey learning terhadap hasil belajar siswa materi operasi aljabar kelas VII.

$\mathrm{Ho}_{2}$ : tidak ada pengaruh penggunaan model pembelajaran guided discovey learning terhadap hasil belajar siswa materi operasi aljabar kelas VII.

\section{Populasi dan Sampel}

Populasi pada penelitian dilakukan di SMP Negeri 2 Sumbergempol Tulungagung paada semester genap tahun ajaran 2017/2018 pada kelas VII SMP. Dari populasi tersebut diambil sampel sebanyak 1 kelas yaitu kelas VII G yang akan mendapatkan model pembelajaran Guided Discovery Learning.

\section{Waktu dan Tempat Penelitian}

Penelitian dilakukan pada tanggal 19 April 2018 bertempat di SMP Negeri 2 Sumbergempol Tulungagung.

\section{Desain Penelitian}

Adapun desain penelitian yang digunakan one-group pretest-posttest design seperti pada gambar sebagai berikut.

$$
\mathrm{O}_{1} \mathrm{X} \mathrm{O}_{2}
$$


Keterangan:

$\mathrm{O}_{1}$ : nilai pretest sebelum pemberian model pembelajaran Guided Discovery Learning.

$\mathrm{O}_{2}$ : nilai posttest setelah pemberian model pembelajaran Guided Discovery Learning.

X : pemberian model pembelajaran Guided Discovery Learning.

\section{Teknik Pengumpulan Data dan Analisis Data}

Teknik pengumpulan data dengan menggunakan metode tes dan dokumentasi.

a. Metode tes

Metode tes adalah cara pengumpulan data dengan memberikan sejumlah pertanyaan kepada siswa yang berkaitan dengan tujuan penelitian. Selajutnya hasil tes operasi aljabar dianalisis untuk menemukan adakah pengaruh model pembelajaran Guided Discovery Learning terhadap kemampuan pemahaman dan hasil belajar siswa materi operasi aljabar kelas VII SMP.

b. Dokumentasi

Dengan metode dokumentasi peneliti untuk mengumpulkan data-data tertulis yang diperlukan dalam penelitian tersebut. Selain dokumentasi tertulis, peneliti juga mengumpulkan dikumentasi berupa foto selama proses penelitian.

Data diperoleh dari hasil kemampuan awal dan kemampuan akhir siswa. Selanjutnya data akan diolah dengan menggunakan uji statistik. Teknik analisis yang diperlukan untuk mengetahui ada atau tidak adanya pengaruh model pembelajaran Guided Discovery Learning terhadap kemampuan pemahaman dan hasil belajar siswa. Hasil penelitian meliputi tes awal (pretest) dan tes akhir (posttest) kemampuan pemahaman dan hasil belajar. Hasil tes akan dianalisis untuk menjawab rumusan masalah penelitian.

Teknik analisis data menggunakan analisis uji-t. Uji prasyarat menggunakan uji normalitas menggunakan Kolmogorov-Smirnov. 


\section{Ferennita Harianti}

\section{HASIL DAN PEMBAHASAN}

Tes kemampuan pemahaman pada penelitian ini berbentuk uraian sebanyak 5 soal dan tes hasil belajar pada penelitian ini berbentuk pilihan ganda sebanyak 10 soal.

\section{Menguji Hipotesis Pertama}

Kemampuan pemahaman siswa dianalisis dengan membandingkan nilai pretest dan posttest. Untuk mengetahui kemampuan pemahaman maka dilakukan uji statistik sebagai berikut.

Berdasarkan data yang telah diperoleh, hasil uji prasyarat analisis yaitu uji normalitas menujukkan sampel dari populasi berdistribusi normal yang dijabarkan sebagai berikut, uji normalitas dengan Kolmogorov-smirnov menggunakan SPSS sehingga diperoleh Asymp. Sig. (2-tailed) untuk nilai sebelum diberi perlakuan sebesar 0,213 dan untuk nilai setelah diberi perlakuan sebesar 0,429. Hal ini berarti 0,213>0,05 dan 0,429>0,05 atau $\mathrm{H}_{0}$ diterima. Dengan demikian data kemampuan pemahaman siswa baik sebelum dan sesudah diberi perlakuan berdistribusi normal. Karena kedua data kemampuan pemahaman siswa baik sebelum dan sesudah berdistribusi normal maka langkah selanjutnya yaitu uji-t dengan hasil sebagai berikut.

Paired Samples Statistics

\begin{tabular}{|cc|c|c|c|c|}
\hline & Mean & $\mathrm{N}$ & Std. Deviation & Std. Error Mean \\
\hline Pair 1 & sebelum & 60.62 & 32 & 8.107 & 1.433 \\
& sesudah & 65.16 & 32 & 7.238 & 1.280 \\
\hline
\end{tabular}

Paired Samples Correlations

\begin{tabular}{|l|c|c|c|}
\hline & $\mathrm{N}$ & Correlation & Sig. \\
\hline Pair 1 sebelum \& sesudah & 32 & .713 & .000 \\
\hline
\end{tabular}


Paired Samples Test

\begin{tabular}{|c|c|c|c|c|c|c|c|c|}
\hline & \multicolumn{5}{|c|}{ Paired Differences } & \multirow[b]{3}{*}{$\mathrm{t}$} & \multirow[b]{3}{*}{ df } & \multirow{3}{*}{$\begin{array}{l}\text { Sig. }(2- \\
\text { tailed) }\end{array}$} \\
\hline & \multirow[b]{2}{*}{ Mean } & \multirow{2}{*}{$\begin{array}{c}\text { Std. } \\
\text { Deviation }\end{array}$} & \multirow{2}{*}{$\begin{array}{c}\text { Std. Error } \\
\text { Mean }\end{array}$} & \multicolumn{2}{|c|}{$\begin{array}{c}95 \% \text { Confidence } \\
\text { Interval of the } \\
\text { Difference }\end{array}$} & & & \\
\hline & & & & Lower & Upper & & & \\
\hline $\begin{array}{ll}\text { Pair } & \text { sebelum - } \\
1 & \text { sesudah }\end{array}$ & -4.531 & 5.869 & 1.038 & -6.647 & -2.415 & -4.367 & 31 & .000 \\
\hline
\end{tabular}

Dari out put analisis dengan menggunakan SPSS di atas diperoleh nilai sig. (2-tailed) sebesar 0,000 sehingga $0,000<0,05$ maka artinya $\mathrm{H}_{0}$ ditolak, dan secara otomatis $\mathrm{Ha}_{1}$ yang diterima. Jadi ada perbedaan yang signifikan antara kemampuan pemahaman siswa sebelum dan sesudah menggunakan model pembelajaran Guided Discovery Learning. Dengan demikian model pemebelajaran Guided Discovery Learning berpengaruh terhadap hasil belajar siswa.

\section{Menguji Hipotesis Kedua}

Hasil belajar siswa dianalisis dengan membandingkan nilai pretest dan posttest. Untuk mengetahui hasil belajar maka dilakukan uji statistik sebagai berikut.

Berdasarkan data yang telah diperoleh, hasil uji prasyarat analisis yaitu uji normalitas menujukkan sampel dari populasi berdistribusi normal yang dijabarkan sebagai berikut, uji normalitas dengan Kolmogorov-smirnov menggunakan SPSS sehingga diperoleh Asymp. Sig. (2-tailed) untuk nilai sebelum diberi perlakuan sebesar 0,014 dan untuk nilai setelah diberi perlakuan sebesar 0,024. Hal ini berarti 0,014>0,05 dan 0,024>0,05 atau $\mathrm{H}_{0}$ diterima. Dengan demikian data hasil belajar siswa baik sebelum dan sesudah diberi perlakuan berdistribusi normal. Karena kedua data hasil belajar siswa baik sebelum dan sesudah berdistribusi normal maka langkah selanjutnya yaitu uji-t dengan hasil sebagai berikut. 


\section{Ferennita Harianti}

Paired Samples Statistics

\begin{tabular}{|c|c|c|c|c|c|}
\hline & & Mean & $\mathrm{N}$ & Std. Deviation & Std. Error Mean \\
\hline \multirow[t]{2}{*}{ Pair 1} & sebelum & 63.44 & 32 & 10.957 & 1.937 \\
\hline & sesudah & 69.06 & 32 & 8.561 & 1.513 \\
\hline
\end{tabular}

Paired Samples Correlations

\begin{tabular}{|l|r|r|r|}
\hline & $\mathrm{N}$ & Correlation & \multicolumn{1}{c|}{ Sig. } \\
\hline Pair $1 \quad$ sebelum \& sesudah & 32 & .689 & .000 \\
\hline
\end{tabular}

Paired Samples Test

\begin{tabular}{|c|c|c|c|c|c|c|c|c|}
\hline & \multicolumn{5}{|c|}{ Paired Differences } & \multirow[b]{3}{*}{$\mathrm{t}$} & \multirow[b]{3}{*}{ df } & \multirow{3}{*}{$\begin{array}{l}\text { Sig. (2- } \\
\text { tailed) }\end{array}$} \\
\hline & \multirow[b]{2}{*}{ Mean } & \multirow{2}{*}{$\begin{array}{c}\text { Std. } \\
\text { Deviation }\end{array}$} & \multirow{2}{*}{$\begin{array}{c}\text { Std. Error } \\
\text { Mean }\end{array}$} & \multicolumn{2}{|c|}{$\begin{array}{c}95 \% \text { Confidence } \\
\text { Interval of the } \\
\text { Difference }\end{array}$} & & & \\
\hline & & & & Lower & Upper & & & \\
\hline $\begin{array}{ll}\text { Pair } & \text { sebelum - } \\
1 & \text { sesudah }\end{array}$ & -5.625 & 8.007 & 1.415 & -8.512 & -2.738 & -3.974 & 31 & .000 \\
\hline
\end{tabular}

Dari output analisis dengan menggunakan SPSS di atas diperoleh nilai sig. (2-tailed) sebesar 0,000 sehingga 0,000 $<0,05$ maka artinya $\mathrm{H}_{0}$ ditolak, dan secara otomatis $\mathrm{Ha}_{2}$ yang diterima. Jadi ada perbedaan yang signifikan antara hasil belajar siswa sebelum dan sesudah menggunakan model pembelajaran Guided Discovery Learning. Dengan demikian model pemebelajaran Guided Discovery Learning berpengaruh terhadap hasil belajar siswa.

Peranan positif guided discovery learning diantaranya mendorong peserta didik berpikir dan bekerja atas inisiatif sendiri, mendorong peserta didik merumuskan hipotesisnya sendiri, membantu peserta didik memperkuat konsep dirinya karena memperoleh kepercayaan bekerja sama dengan yang lain (Hosnan, 2014: 287) dalam Riftakhul Ardi Bakhtiyar. Tingginya hasil 
belajar siswa yang mengikuti pembelajaran dengan model pembelajaran Guided Discovery Learning tidak terlepas dari keaktifan siswa dalam kegiatan pembelajaran, siswa mempergunakan ide, konsep dan ketrampilan yang sudah mereka pelajari untuk menemukan pengetahuan baru dan menarik kesimpulan. Siswa benar-benar dituntut aktif, disini guru berperan sabagai fasilitator yaitu membimbing dan memonitor tiap kelompok untuk memantau kegiatan siswa sampai selesai.

\section{KESIMPULAN}

Berdasarkan hasil dan pembahasan penelitian yang diperoleh pada pengaruh model pembelajaran guided discovery learning terhadap kemampuan pemahaman dan hasil belajar siswa materi operasi aljabar kelas VII SMP Negeri 2 Sumbergempol dapat disimpulkan bahwa kemampuan pemahaman siswa terhadap materi operasi aljabar setelah mendapatkan model pembelajaran guided discovery learning menggunakan uji-t diperoleh $0,000<0,05$ maka artinya $\mathrm{H}_{0}$ ditolak, dan secara otomatis $\mathrm{Ha}_{1}$ yang diterima artinya ada pengaruh penggunaan model pembelajaran guided discovey learning terhadap kemampuan pemahaman siswa materi operasi aljabar kelas VII. Sedangkan hasil belajar siswa terhadap materi operasi aljabar setelah mendapatkan model pembelajaran Guided Discovery Learning menggunakan uji-t diperoleh $0,000<0,05$ maka artinya $\mathrm{H}_{0}$ ditolak, dan secara otomatis $\mathrm{Ha}_{2}$ yang diterima artinya ada pengaruh penggunaan model pembelajaran guided discovey learning terhadap hasil belajar siswa materi operasi aljabar kelas VII. Berdasarkan uraian tersebut dapat disimpulkan bahwa model pembelajaran Guided Discovery Learning lebih efektif dibandingkan dengan model pembelajaran konvensional.

\section{DAFTAR PUSTAKA}

Bakhtiyar, Riftakhul Ardi. (2017). Pengaruh Model Pembelajaran Guided Discovery Learning terhadap Penguasaan Konsep Matematika. Surakarta: Universitas Muhammadiyah Surakarta.

Risnawati. (2008). Strategi Pembelajaran Matematika. Pekanbaru: Suska Press. Firdaus, dkk. (2015). Pengaruh Model Pembelajaran Penemuan Terbimbing (Guided Discovery Learning) terhadap Hasil Belajar Matematika Siswa 
Kelas VIII SMP Negeri 2 Kepenuhan pada Materi Persegi Panjang dan Segitiga. Pasir Pangairan: Universitas Pasir Pangairan.

Ulfa, Khilya, dkk. (2017). Efektivitas Model Guided Discovery Learning untuk Video Pembelajaran dalam Mengetahui Perbedaan Kemampuan Pemecahan Masalah Matematika Siswa. MUST: Journal of Mathematics Education, Science and Technology, Vol. 2, No. 2, 267-275.

Kholik, Abdul, dkk. (2016). Peningkatan Hasil Belajar Matematika melalui Model Pembelajaran Kooperatif Tipe Guided Inquiry Pokok Bahasan Garis Singgung Lingkaran pada Siswa Madrasah Tsanawiyah. MUST: Journal of Mathematics Education, Science and Technology, Vol. 1, No. 1, $1-9$.

Satyawati. (2011). Pengaruh Model Pembelajaran Penemuan Terbimbing Berbasis LKS terhadap Hasil Belajar Matematika Siswa Ditinjau dari Kecerdasan Logis Matematis pada Siswa Kelas X SMAN 1 Bangli. Jurnal Penelitian Pasca sarjana Undiks, 2(2), 1-17.

Hosnan. 2014. Pendekatan Saintifik Dan Kontekstual Dalam Pembelajaran Abad 21. Bogor: Ghalia Indonesia. 